\title{
Increases in DNA and Protein Syntheses in Human Umbilical Vein Endothelial Cells Treated with Asbestos
}

\author{
Yuji Karasaki ${ }^{1}$, Hajime Urano ${ }^{2}$, Akira Shirahata ${ }^{2}$, Ziro Nambu' ${ }^{1}$, Taro OhJi ${ }^{3}$, \\ Masayoshi Miura and Sadao GoToH ${ }^{4}$
}

'School of Health Sciences, ${ }^{2}$ Department of Pediatrics and ${ }^{4}$ Biochemistry, School of Medicine, University of Occupational and Environmental Health and ${ }^{3} \mathrm{St}$. Lucia Hospital

\begin{abstract}
Increase in DNA and Protein Syntheses in Human Umbilical Vein Endothelial Cells Treated with Asbestos: Yuji Karasakı, et al. School of Health Sciences, University of Occupational and Environmental Health-When human umbilical vein endothelial cells (HUVECs) were treated with crocidolite asbestos, HUVECs phagocytized the fibers; no cytotoxic effect was observed when treated at concentrations lower than $10 \mu \mathrm{g} / \mathrm{m} l$ for $24 \mathrm{~h}, 48 \mathrm{~h}$ and $72 \mathrm{~h}$. The time-dependent effect of crocidolite asbestos on DNA synthesis and protein synthesis in HUVECs was studied. The DNA synthesis of the cells exhibited the maximum augmentation (150\%) at $24 \mathrm{~h}$, and the protein synthesis increased to the maximal value $(140 \%)$ at $36 \mathrm{~h}$. The dose-dependent effect of crocidolite asbestos on DNA synthesis and protein synthesis in HUVECs was also studied. The maximum increases in DNA synthesis and protein synthesis were observed at $5 \mu \mathrm{g} / \mathrm{m} l$ and at $10 \mu \mathrm{g} / \mathrm{m} l$ of the fibers, respectively. An apparent increase in DNA synthesis may be mainly due to the repair of DNA damage induced by asbestos under our present experimental conditions, but also in part due to the mitogenic effect of asbestos. Cell injury and DNA damage will remain for a while in the cells, and asbestos fibers phagocytized into cells may induce not only specific but also nonspecific gene transcriptions, which might promote mutations in HUVECs and asbestosis.

(J Occup Health 1998; 40: 302-306)
\end{abstract}

Key words: Asbestos, Human umbilical vein endothelial cell, DNA and protein syntheses

Exposure of humans to abestos causes inflammation and fibrosis of the pulmonary interstitium and peripheral airspaces $^{1)}$. Morphological studies have shown that

Received Apr 2, 1998; Accepted Sept 11, 1998

Correspondence to: Y. Karasaki, School of Health Sciences, University of Occupational and Environmental Health, 1-1 Iseigaoka, Yahatanisi-ku, Kitakyushu 807-0804, Japan asbestos in the interstitial space ultimately deposits in alveolar macrophages ${ }^{2,31}$, but asbestos particulates have also been found in interstitial fibroblasts, type I epithelial cells and capillary endothelial cells as well as the area around the basement membranes of capillary endothelial cells ${ }^{1)}$. Although phagocytic cells have been extensively studied in connection with the cytotoxicity of asbestos fibers in vitro ${ }^{4,5)}$, asbestos-induced cell activation is still under study ${ }^{6}$. Phagocytosis of asbestos fibers by endothelial cell was previously reported ${ }^{7}, 8$. So far, however, the changes in DNA and protein syntheses induced by asbestos have not been studied. In the present study we investigated whether asbestos fibers phagocytized into human umbilical vein endothelial cells (HUVECs) affected DNA and protein syntheses of the cells, and we discussed changes in cell function induced by phagocytosis.

\section{Materials and Methods}

Reagents

The crocidolite asbestos fibers were standard, finely ground UICC reference samples kindly provided by the Pneumoconiosis Research Unit of the South African Medical Research Council, Johannesburg.

The culture medium for HUVECs consisted of modified MCDB 131, 2\% (v/v) fetal calf serum (FCS), $10 \mathrm{ng} / \mathrm{m} l$ of epidermal growth factor (EGF), acidic fibroblast growth factor (aFGF) $4 \mathrm{ng} / \mathrm{m} l$, heparin $25 \mu \mathrm{g} /$ $\mathrm{m} l, 1 \mu \mathrm{g} / \mathrm{m} l$ of hydrocortisone, and antibiotics $(50 \mu \mathrm{g} / \mathrm{m} l$ of gentamicin sulfate).

Acetylated low density lipoprotein labeled with 1,1 'dioctade y $1-1-3,3,3$ ' 3'-tetramethy 1 - indocarbocyanineperchola (DilAc-LDL) was purchased from Biomedical Technologies, Stoughton, MA, U.S.A. An immunohistochemical staining kit for the human factor VIII related antigen was purchased from Biomeda Co., Foster, CA, U.S.A. MCDB131 was purchased from Sigma Chemical Co. Ltd. $\left[{ }^{3} \mathrm{H}\right]$ Thymidine $(925 \mathrm{GBq} /$ 
$\mathrm{mmol})$ and $\left[4,5-{ }^{3} \mathrm{H}\right]$ Leucine $(6.0 \mathrm{TBq} / \mathrm{mol})$ were purchased from Amersham Corp. All other reagents were purchased from Wako Pure Chemicals, Osaka, Japan.

\section{Cell Culture}

Vascular endothelial cells were isolated from human umbilical cord veins according to the method of Jaffe et $a l .{ }^{91}$, and grown in gelatin coated $25 \mathrm{~cm}^{2}$ flasks containing the culture medium in a $5 \% \mathrm{CO}_{2}$ atmosphere at $37^{\circ} \mathrm{C}$. The endothelial cell monolayer was identified by the typical cobblestone morphology, the presence of von Willebrand factor and Factor VIII complex which was detected by indirect immunostaining and uptake of DilAc-LDL ${ }^{103}$. The cells of the third passage were grown to confluence in 96-well or 24-well plates without gelatin coating. These cells were used in the experiments 1 to 3 days after confluence.

\section{Cell Counting}

All data were normalized according to the number of cells in each well. The number of cells was determined by a tetrazolium/formazan assay in which the $490 \mathrm{~nm}$ absorbance of formazan produced from tetrazolium compound (3-[4,5-dimethylthiazol-2-yl-5[3carboxymethoxyphenyl]-2-[4-sulphenyl]-2H-tetrazolium, inner salt; MTS) was correlated to the number of viable cells, with CellTiter96TM (Promega Co., Madison, USA). In a preliminary experiment, we confirmed that the result of the tetrazolium/formazan assay was well correlated with the number of cells counted with a hemocytometer under a light microscope.

\section{Treatment of Cells with Fibers}

The medium was removed from wells, and a fresh medium containing crocidolite asbestos fibers was poured into each well. The plates were placed in a $\mathrm{CO}_{2}$ incubator at $37^{\circ} \mathrm{C}$ for the periods indicated until the time of the following assays.

\section{Cyototoxicity Assay}

HUVECs were grown to confluence in the wells of a 96-well plate, and exposed to the fresh medium containing the fibers $(2.5,5,10,25,50 \mu \mathrm{g} / \mathrm{m} /)$ for 24,48 and $72 \mathrm{~h}$ in a $\mathrm{CO}_{2}$ incubator at $37^{\circ} \mathrm{C}$. Then the cytotoxicity was assessed by lactic dehydrogenase assay with Cyto Tox 96 (Promega Co. Madison, USA). The CytoTox96 assay quantitatively measures the activity of lactate dehydrogenase (LDH) that has been released into the medium upon cell lysis; this assay measures the conversion of a tetrazolium salt (INT) into a red formazan product. The amount of color formed in the assay is proportional to the number of lysed cells.

\section{$\left[{ }^{3} H\right]$ Thymidine Incorporation}

HUVECs were cultured in the wells of a 96-well plate with or without crocidolite fibers for the times indicated. $\left[{ }^{3} \mathrm{H}\right]$ thymidine was then added to a final concentration of $1 \mu \mathrm{Ci} / \mathrm{m} l$ and the cells were incubated for an additional 3 $h$. The cells were harvested and the radioactivity incorporated was determined by a liquid scintillation counter.

\section{Assay of Protein Synthesis}

HUVECs were cultured in the wells of a 24-well plate with or without crocidolite fibers for the times indicated. $\left[{ }^{3} \mathrm{H}\right]$ leucine was then added to a final concentration of 1 $\mu \mathrm{Ci} / \mathrm{m} l$ and the cells were incubated for an additional 3 $\mathrm{h}$. The cells were treated with trypsin, harvested, had 2 $\mathrm{m} l$ of ice-cold $20 \%$ Trichloroacetic Acid (TCA) added, mixed and chilled on ice for $10 \mathrm{~min}$. The precipitate was collected by filtering the mixture through a glass-fiber disc. The filter was washed twice with $2 \mathrm{~m} l$ of ice-cold $10 \%$ TCA and once with $5 \mathrm{ml}$ of $95 \%$ ethanol, and the radioactivity precipitated was determined by a liquid scintillation counter.

\section{Statistical Analysis}

Data are expressed as the mean \pm S.E. Student's twotailed unpaired $t$-test for data was used to compare differences between means, with significance at $\mathrm{p}<0.05$.

\section{Results and Discussion}

Phagocytosis of Crocidolite Asbestos Fibers by HUVECs

Figure 1 shows that most HUVECs contain crocidolite fibers, and the fibers are membrane-bounded and/or in the cytoplasm, which agrees with earlier reports on phagocytosis of asbestos fibers by endothelial cells ${ }^{6,7}$. In most of the cells, few morphological changes were observed under the light microscope.

\section{Cytotoxic Effect of Crocidolite Asbestos Fibers on HUVECs}

To estimate the effect of crocidolite asbestos on cell viability, HUVECs were exposed to crocidolite fibers for the periods indicated and lactate dehydrogenase (LDH) release was quantified. Fig. 2 shows the dose-dependent cytotoxic effects of asbestos fibers on the HUVEC monolayers. No cytotoxicity was observed when the cells were treated with the fibers at concentrations lower than $10 \mu \mathrm{g} / \mathrm{ml}$ for $24 \mathrm{~h}, 48 \mathrm{~h}$ and $72 \mathrm{~h}$, but significant cytotoxicity was observed at $50 \mu \mathrm{g} / \mathrm{ml}(50 \%)$. No statistical difference was observed among the $24 \mathrm{~h}, 48 \mathrm{~h}$ and $72 \mathrm{~h}$ treatments with crocidolite asbestos on cytotoxicity at or less than $50 \mu \mathrm{g} / \mathrm{m} l$ of the fiber.

\section{Time-Dependent Effects of Crocidolite Asbestos on DNA and Protein Syntheses in HUVECs}

HUVECs were incubated with $5 \mu \mathrm{g} / \mathrm{m} l$ of crocidolite asbestos for the periods indicated, and DNA and protein syntheses were determined (Fig. 3). The DNA synthesis 


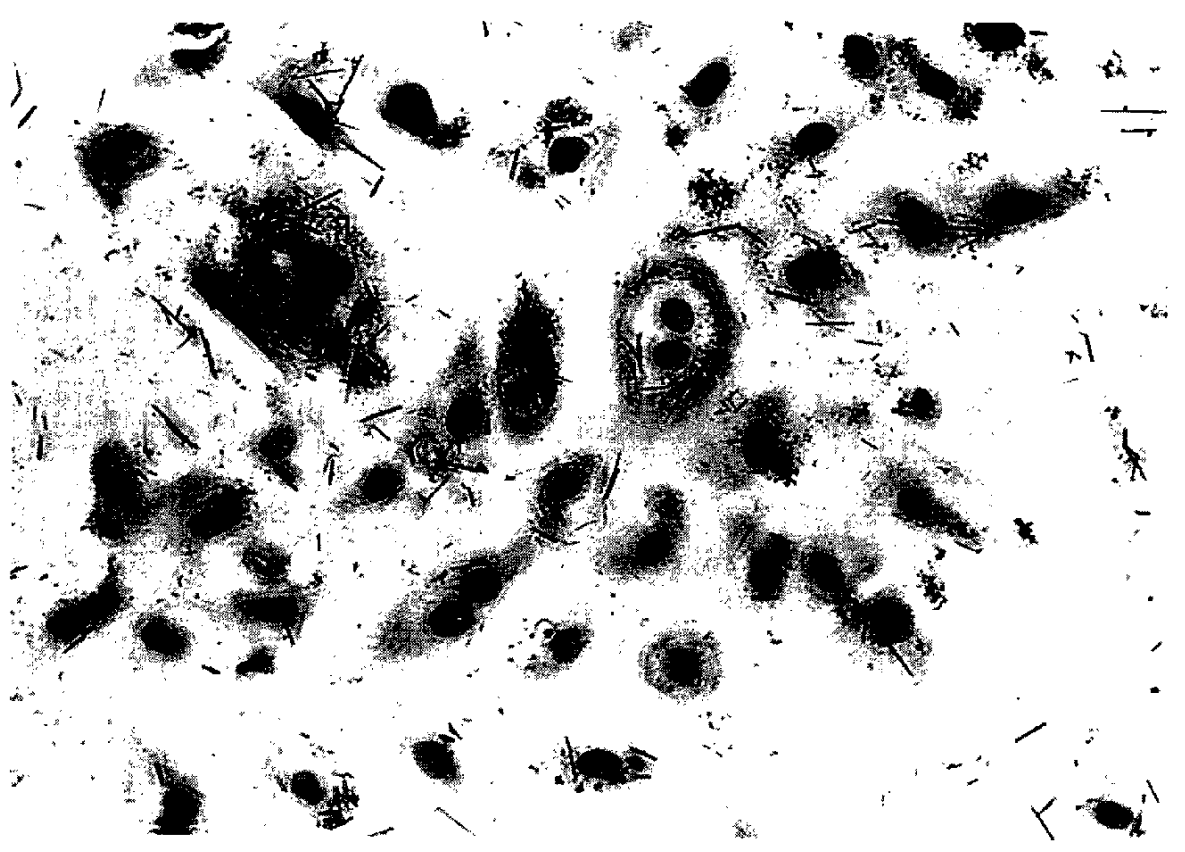

Fig. 1. Phagocytosis of crocidolite asbestos fibers by HUVECs. HUVECs were grown to subconfluence on a gelatin-coated glass coverslip and then the cells were exposed to fresh medium containing crocidolite asbestos fibers $(5 \mu \mathrm{g} / \mathrm{m} l)$ for $24 \mathrm{~h}$. After being washed, the cells were fixed with $100 \%$ methanol, stained with $4 \%$ giemasa dye and examined by light microscopy with a magnification of $\times 400$.

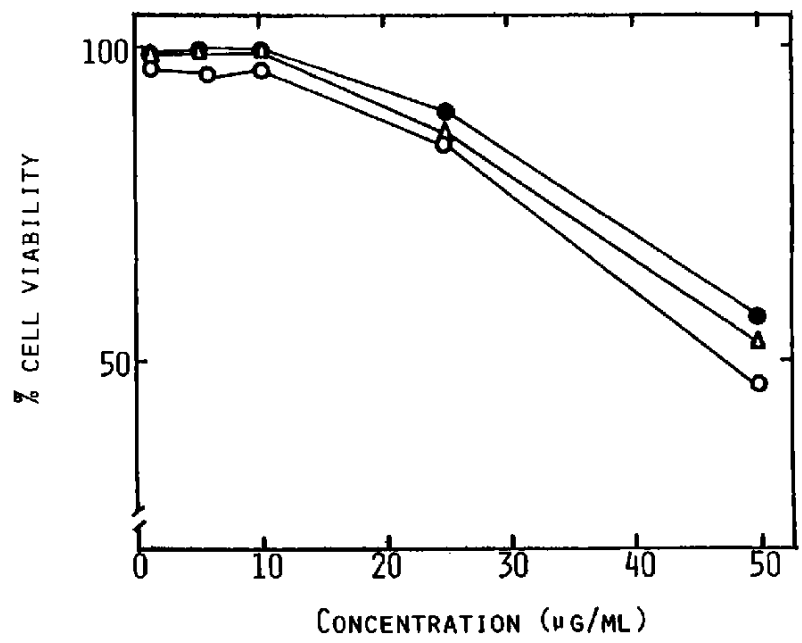

Fig. 2. Dose-dependent cytotoxic effects of crocidolite asbestos on HUVECs. HUVECs were grown to confluence in the wells of a 96-well plate. After the cells were treated with crocidolite asbestos for $24 \mathrm{~h}(\boldsymbol{O})$, $48 \mathrm{~h}(\triangle)$ and $72 \mathrm{~h}(\mathrm{O})$, cell viability was assayed. Cell viability represents the percentage of live cells among the whole population of cells. All data are averages \pm SE from penta wells in two independent experiments. The value represents the mean of the experimental data, and data points were within $5 \%$ of the mean. of the cells reached the maximum level $(150 \%)$ at $24 \mathrm{~h}$, and was still high (120\%) at $48 \mathrm{~h}$, and thereafter began gradually to decrease, and reached the control level of untreated cells at $72 \mathrm{~h}$ after the beginning of treatment. No effect of the fibers on DNA synthesis was observed over $12 \mathrm{~h}$ during the incubation with the fibers. It was reported that increased incorporation of $\left[{ }^{3} \mathrm{H}\right]$ thymidine occurred between 19 and $33 \mathrm{~h}$ in epithelial and interstitial cells of rats after exposure to asbestos fibers for $5 \mathrm{~h}^{11)}$. We observed similar time-dependent effects of the fibers on HUVECs in our present study. The protein synthesis, on the other hand, increased to its maximal value (140\%) at $36 \mathrm{~h}$ and thereafter slowly decreased for more than 36 $\mathrm{h}$, but the protein synthesis at $96 \mathrm{~h}$ was still higher than the untreated control value. No effect was observed on protein synthesis during the incubation with the fibers for less than $24 \mathrm{~h}$. DNA synthesis reached its maximum level $12 \mathrm{~h}$ earlier than protein synthesis, which may reflect the ordinary direction of the flow of synthetic pathways in which DNA and RNA syntheses proceed in protein synthesis.

Dose-Dependent Effect of Crocidolite Asbestos on DNA and Protein Syntheses in HUVECs

HUVECs were incubated with different concentrations $(1.25,2.5,5,10$, and $20 \mu \mathrm{g} / \mathrm{m} /)$ of crocidolite asbestos for $24 \mathrm{~h}$ and $36 \mathrm{~h}$ to assess the effect on DNA and protein 


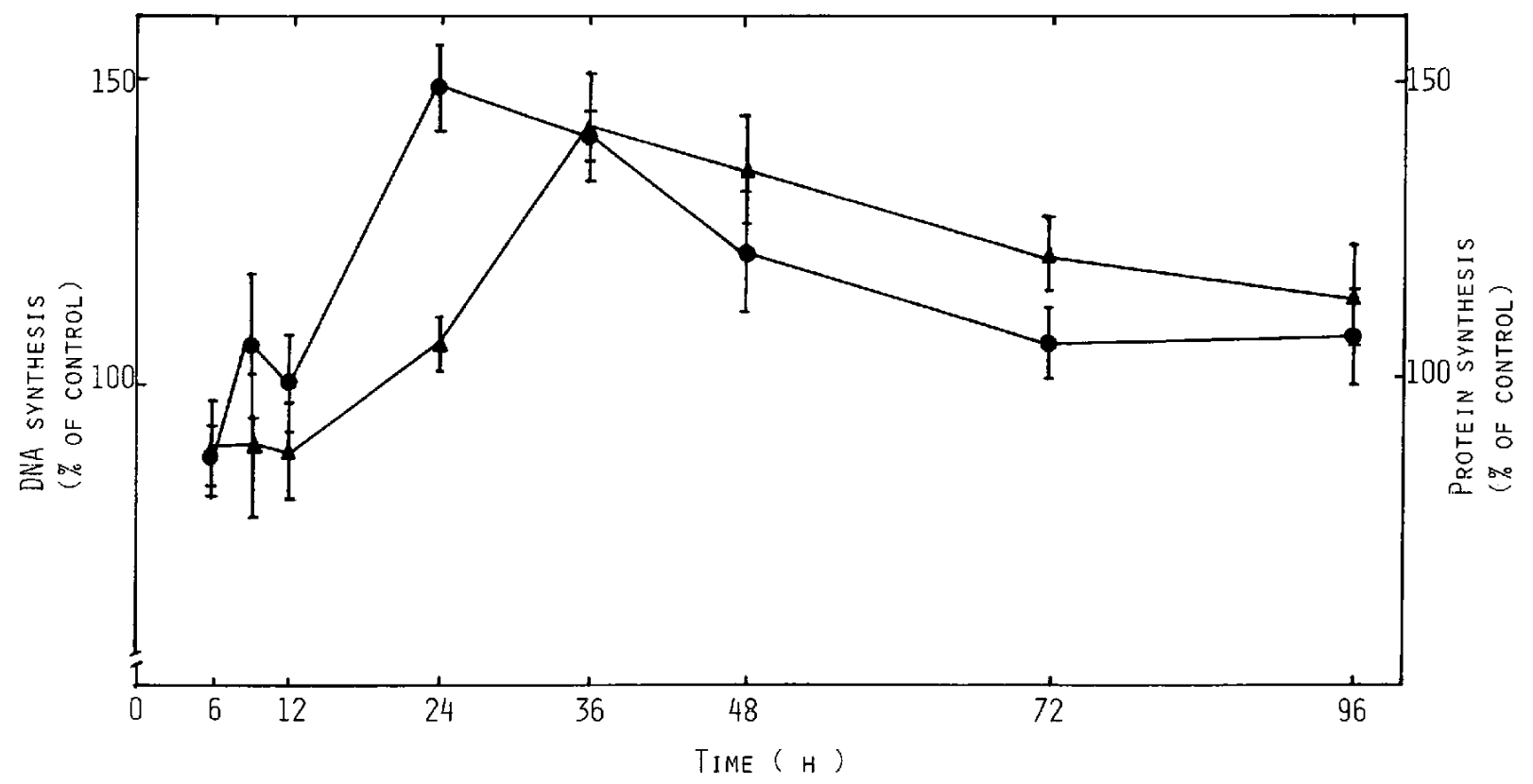

Fig. 3. Time-dependent effects of crocidolite asbestos on DNA and protein syntheses in HUVECs. HUVECs were grown to confluence in the wells of a 96-well or 24-well plate. After they were incubated with crocidolite asbestos at $5 \mu \mathrm{g} / \mathrm{m} /$ for the periods indicated, DNA and protein syntheses were determined ( data are averages \pm SE from triplicate wells of three independent experiments.

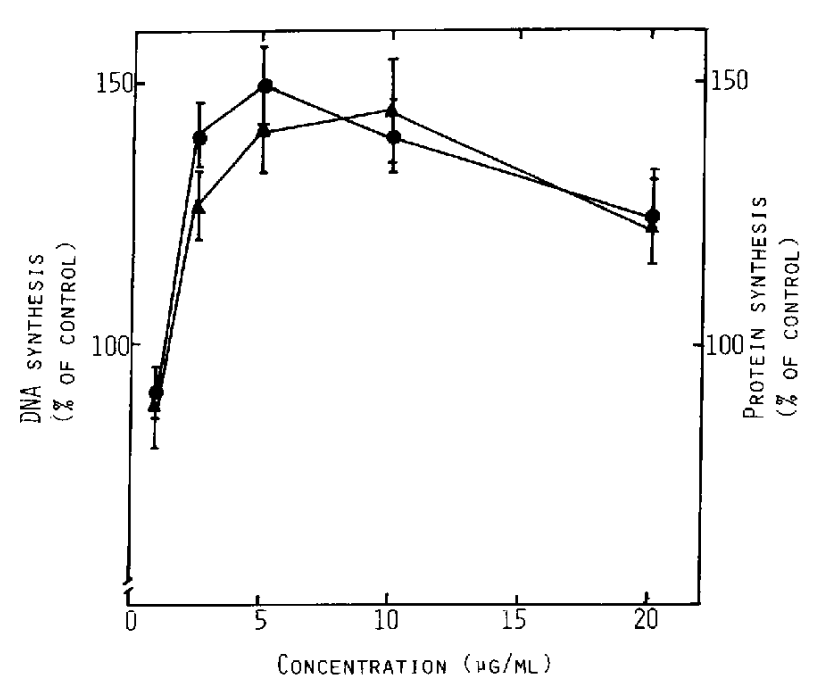

Fig. 4. Dose-dependent effects of crocidolite asbestos on DNA and protein syntheses in HUVECs. HUVECs were grown to confluence in the wells of a $96-$ well or a 24-well plate. After they were treated with different concentrations of crocidolite asbestos $(1.25,2.5,5,10$, $20 \mu \mathrm{g} / \mathrm{m} l$ ) for $24 \mathrm{~h}(\mathbf{O}$; DNA synthesis), or $36 \mathrm{~h}$ (A; protein synthesis), DNA and protein syntheses were determined. All data are averages \pm SE from triplicate wells in three independent experiments. syntheses, respectively (Fig. 4). A significant increase $(150 \%)$ in DNA synthesis was observed when the cells were treated with the fibers at $5 \mu \mathrm{g} / \mathrm{m} l$ and a similar increase was observed at $2.5,10 \mu \mathrm{g} / \mathrm{ml}$, but only a little increase $(125 \%)$ at $20 \mu \mathrm{g} / \mathrm{m} l$. The incubation with the fibers at $1 \mu \mathrm{g} / \mathrm{ml}$ induced no effect. The maximum protein synthesis (145\%) was observed at $10 \mu \mathrm{g} / \mathrm{ml}$. As for protein synthesis, no statistical difference in the effects of the fibers was observed between the $5 \mu \mathrm{g} / \mathrm{ml}$ and 10 $\mu \mathrm{g} / \mathrm{m} l$ concentrations, but the 2.5 and $20 \mu \mathrm{g} / \mathrm{m} l$ concentrations were less effective than the $10 \mu \mathrm{g} / \mathrm{m} l$ $(p<0.05)$ concentration. No effect was observed on protein synthesis at $1 \mu \mathrm{g} / \mathrm{m} l$. These results indicate that the dose-dependent pattern of the effect of crocidolite asbestos on protein synthesis was very similar to that on DNA synthesis.

Studies with animals demonstrated that asbestos is taken up by alveolar type I epithelial cells soon after the exposure; this is followed by a morphological change in epithelial cell injury at sites of fiber deposition and the triggering a proliferative response by alveolar type II cells $^{11,12)}$. It was reported that asbestos caused DNA base pair modifications and DNA strand breaks in pulmonary epithelial cells and DNA repair mechanisms could be overwhelmed after long-term exposure to low dose asbestos $^{13)}$. Since cell proliferation and cytotoxicity were not detected under our experimental conditions, the increase in DNA synthesis may be mainly due to the repair of DNA damage induced by asbestos, and in part due to 
the mitogenic effect of asbestos. Furthermore, cell injury and DNA damage may remain for a while and cause an activation of not only specific but also nonspecific gene transcription in the cells. Enhanced activity of various kinds of proteins was observed in the cells treated with asbestos $^{7,14}$. The increase in protein synthesis found in the present study may induce the abnormal production of regulatory factors, which might alter some of the mechanisms regulating gene expression. Tobacco smoking is known to cause all types of lung cancer and carcinogens in tobacco smoke directly cause K-ras mutations, and asbestos may favor recruitment of K-ras mutation positive cells by stimulating cellular growth in the multistage process of carcinogenesis ${ }^{15}$. It has been reported that asbestos-induced endothelial cell injury and changes in cell functions would appear to be mediated via oxidant-dependent mechanisms and endothelial cell activation may be an important step toward asbestosis ${ }^{6}$.

Taken together, the present results showed that the asbestos fibers phagocytized by HUVECs significantly increased DNA and protein syntheses in the cells, which may promote oncogenic mutations in these cells and asbestosis.

\section{References}

1) Sheppard MN, Harrison NK. Lung injury, inflammatory mediators, and fibroblast activation in fibrosing alveolitis. Thorax 1992; 47: 1064-1074.

2) Barry BE, Wong KC, Brody AR, Crapo JD. Reaction of rat lungs to inhaled chrysotile asbestos following acute and subchronic exposures. Exp Lung Res 1983; 5: $1-21$.

3) Pinkerton KE, Pratt PC, Brody AR, Crapo JD. Fiber localization and its relationship to lung reaction in rats after chronic inhalation of chrysotile asbestos. Am J Path 1984; 117: 484-498.

4) Harington JS, Miller K, Macnab G. Hemolysis by asbestos. Environ Res 1971; 4: 95-117.

5) Elke B, Harington JS. Cytotoxic effects of some mineral dusts on syrian hamster peritoneal macrophages. J Exp Med 1971; 133: 1149-1169.

6) Garcia JGN, Gray LD, Dodson RF, Callahan KS. Asbestos-induced endothelial cell activation and injury. Am Rev Respir Dis 1988; 138: 958-964.

7) Garcia JGN, Dodson RF, Callahan KS. Effect of environmental particulates on cultured human and bovine endothelium. Laboratory Investigation 1989; 61: 53-61.

8) Barry BE, Wong KC, Brody AR, Crapo JD. Reaction of rat lungs to inhaled chrysotile asbestos following acute and subchronic exposures. Exp Lung Res 1983; 5: $1-21$.

9) Jaffe EA, Nachman RL, Becker CG, Minick CR. Culture of human endothelial cells derived from umbilical veins. J Clin Invest 1973; 52: 2745-2756.

10) Netland PA, Zetter BR, Via DP, Voyta JC. In situ labelling of vascular endothelium with fluorescent acetylated low density lipoprotein. Histochem J 1985; 17: 1309-1320.

11) Brody AR, Overby LH. Incorporation of tritiated thymidine by epithelial and interstitial cells in bronchiolar alveolar regions asbestos-exposed rats. Am J Pathol 1989; 134: 133-140.

12) Brody AR, Hill LH, Adkins B Jr, O'connor RW. Chrysotile asbestos inhalation in rats: Deposition pattern and reaction of alveolar epithelium and pulmonary macrophages. Am Rev Respir Dis 1981; 123: 670-679.

13) Kamp DW, Israbian VA, Preusen SE, Zhang CX, Weitzman SA. Asbestos causes DNA strand breaks in cultured pulmonary epithelial cells: Role of ironcatalyzed free radicals. Am J Physiol 1995; 268: L47IL480.

14) Fujino A, Hori H, Higashi T, Morimoto $Y$, Tanaka I, Kaji H. In-vitro biological study to evaluate the toxic potentials of fibrous materials. Int $J$ Occup Environ Health 1995; 1: 21-28.

15) Vaino H, Husgafvel-Pursiainen $K$, Anttila $S$, Karjalainen A, Hackman P, Partanen T. Interaction between smoking and asbestos in human lung adenoccarcinoma: Role of K-ras mutations. Environ Health Perspect Suppl 1993; 101: 189-192. 